\title{
The Assessment Process in Teaching and Learning English in The Midst of Covid-19 Pandemic
}

\author{
Ni Nyoman Diah Werdiyanti \\ Universitas Pendidikan Ganesha, Bali \\ diahwerdiyanti25@gmail.com
}

\begin{abstract}
The spread of Corona Virus Disease (COVID-19) made changes in education sector. The teaching and learning process change from blended learning into fully online learning. All the instructions are conducted fully online even the assessment, the important role in teaching and learning process, both the formative and summative assessment. The design of this study was Basic Interpretative Study. This study aimed to investigate the methods used by teachers in conducting the assessment as well as the challenges in doing assessment in fully online learning situation. High School English teachers were chosen to be the subject of this study. The results showed that teachers used Eportfolios, Self-assessment, and teachers' feedback as the formative assessment and daily test, mid-terms test, final test in the forms of multiple choice, short answer, and essays, and final project as the summative assessment. However, teachers also found some difficulties in doing assessment in today's online learning. Thus, the authorized government and other stakeholders are expected to hold seminar(s) or training(s) for teachers and provide appropriate services. Moreover, teachers are expected to enrich their assessment and digital literacy by joining seminar(s), webinar(s), or training(s).
\end{abstract}

\section{Keywords: Formative Assessment, Online Learning, Summative Assessment \\ INTRODUCTION}

The significant development of Technology has transformed traditional learning into learning combined with online learning known as blended learning. Watson, et.al (2010) as cited in Bakia et al., (2012) said that Blended learning is a form of learning where students get most of the instructions face to face and online. According to Bakia et al., (2012), Online learning is learning with internet support consisting of various internet-based programs, within and beyond school walls to provide access to learning material and as a facility for interaction between teachers and students. Dhull \& Sakshi (2019) say that various technologies are included in online learning such as the worldwide web, e-mail, chat, new groups and texts, audio and video conferences delivered through computer networks to provide education. They add that these technologies help students learn according to their own pace and comfort.

Today's situation forced teachers to conduct all instructions fully online. The spread of the Corona virus disease (COVID-19) has spread in almost all parts of the world. As one of the countries with a high infection rate of covid-19, Indonesia has made various changes in various fields, of which the education sector is one of them. One of the efforts is the implementation of Belajar Dari Rumah (BDR) or in English called as Learn from Home. This means, there is a 
change in the learning process in the midst of this pandemic, from blended learning into fully online learning. The objectives of applying Learn from home are ensuring the fulfillment of the rights of students to obtain educational services during COVID-19 emergencies, protecting citizens of educational units from the adverse effects of COVID-19, preventing the spread and transmission of COVID- 19 in the education unit, and ensuring the fulfillment of psychosocial support for educators, students and parents / guardians. This has been stated in Circular No. 4 of 2020 issued by the Indonesian Ministry of Education and Culture, concerning the implementation of education in the Covid-19 emergency period.

Due to the fully online learning situation, the important role in teaching and learning process, assessment, should also be carried out online. Wojtczak (2002) argues that Assessment could help teachers to evaluate students' strengths and weakness as well as give motivation to their students. Assessments are divided into two namely summative assessment and formative assessment. Both of them should be implemented in balance. Broadbent et al., (2018) said that when summative assessment and formative assessment are combined and harmonized, the learning environment will be strengthened and students will feel what they are actually improving, not just what they are producing. Summative assessment is an evaluation of student learning and teacher teaching after learning is carried out (Brookhart \& Nitko, 2019). According to States et al., (2018), Summative assessment is an assessment of learning that occurs at the end of the instructional unit or is carried out at a certain time. They added that in summative assessment, knowledge will be measured against a predetermined standard or benchmark and this provides a metric about what works and what doesn't work in the teaching and learning process. Meanwhile, Shaoqian (2003) said that Summative assessment is an assessment made by the teacher based on the teacher's curiosity about what students can remember and understand about the related learning material. In contrast, According to $\mathrm{Qu}$ \& Zhang (2013), Formative assessment is the "investigation, evaluation and analysis of record of daily students' learning activities". They added that this assessment provides teachers with more detailed information and a comprehensive understanding of what students need so that teachers can provide continuous feedback and use teaching methods that are appropriate to their students' needs. States et al., (2018) added that formative assessment serves to measure student progress as well as a diagnostic tool used to help students improve their skills or solve problems they are experiencing.

English is still the most popular foreign language in Indonesian schools. It remains the first foreign language. As a foreign language, English has gained a special status among other foreign languages in Indonesia due to many real causes (Lauder, 2008). Constant practice and patience is required to learn English. Most students learn English only from the point of view of the exam, so students only know about what English is, not about how to use it. (Nishanthi, 2018). Teaching English is not easy. With different skill levels in each class, teachers must use effective strategies that allow students to learn the material. Teachers must be creative in choosing material and be able to stimulate student interest. According to Lestari et al., (2019), teachers must be able to encourage students' enthusiasm in learning English and find effective strategies to make students interested and reduce the level of student boredom. They said that this 
can be done by inserting brainstorming, games, interactive discussions, etc. On the other hand, Nguyen and Terry (2017) said that here are several factors that influence the strategy and process of learning English at this time, namely individual talent, perseverance, hard work, and positive attitudes from teachers and students. Therefore, teachers need to manipulate several strategies to support the teaching and learning process. In the midst of COVID-19, it is very important for teacher to use the right strategy in implementing the assessment that allows students to learn and to improve their selves.

Barbosa and Garcia (2005) in their research showed that assessment was an important and interoperable in online learning. As such, assessment tools can be used with different content, concepts, resources, and ways to design and implement exams for students. The Assessment process in today's online learning should still be conducted, not only in summative way but also formatively. In today's online learning High School English teachers in Mengwi have been conducting assessment both summative and formative assessment. However in the process of the assessment itself, many obstacles faced by the teachers. Thus, this study was conducted to investigate the method used by teachers in assessing students as well as the challenges faced by the teachers.

\section{METHOD}

This study was a qualitative study. The design used in this study was basic interpretative study. According to Ary, et.al. (2010), the purpose of Basic interpretative study is to investigate a phenomenon, a process, or people's perspective towards particular phenomenon. In this study, the basic interpretative study is used to investigate the method of the assessment process as well as the challenges in conducting the assessment process during the online learning environment. The subject of this study was high school teachers in Mengwi. To know the method of the assessment process in teaching and learning process as well as the challenges faced by the teachers, the researcher conducted interviews to the respondents. Data analysis was performed using the techniques proposed by Miles et al., (2014) consisting of data collection, data reduction, data display, and conclusion drawing.

\section{FINDINGS \& DISCUSSIONS}

In the online learning environment in the midst of covid-19 pandemic, high school teachers in Mengwi conducted several kinds of assessment. Those assessments included both formative and summative assessment. However, the proportion was different. They could not do the formative assessment as often as summative assessment. This was because not all topic of material could be assessed formatively. Moreover, it was also found that in conducting the assessments, both formative and summative assessment, teachers found several difficulties.

Teachers used several methods in conducting both formative and summative assessment. In conducting formative assessment, teachers used Eportfolios, Self-assessment, and teachers' feedback. Every teachers implemented different methods in conducting assessment. This was showed in teachers' statement below

"I used only teachers' feedback and students' self-assessment in conducting formative assessment in today's online learning. Those were I think the best way to make the improvement for my students" (R1) 
"I considered using e-portfolio and giving feedback to my students to give assessment formatively. Thus, they can always recall their assignments as well as my feedback" (R2)

'Students submit their works and I give feedback to the students' works through the Google classroom. Sometimes I also asked them to do selfassessment to reflect on themselves on what they have done" (R3)

Those were also showed on the Figure 1. and Figure 2. Below

Figure 1. Students' Self-Assessment

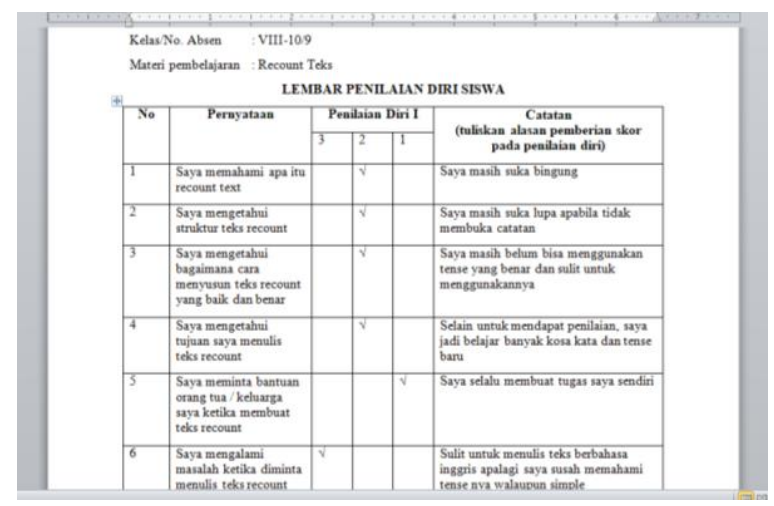

Figure 2. Teachers' Feedback

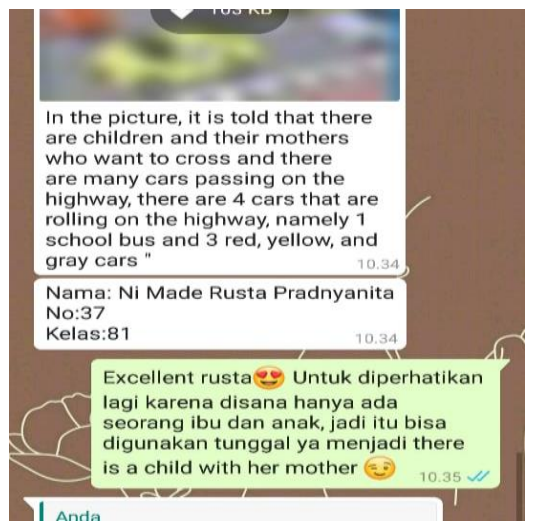

Teachers said that E-portfolios help teachers and also students to recall students' works and teachers' feedback. In this case, all of the students' works and also teachers' feedback were collected in one folder on a platform. By having e-portfolios teachers could see their students' improvement easily and students also could see what should be improved in every project easily. Amaya et al., (2013) said that the use of e-portfolios is very important to improve the teaching and learning process as well as student assessment. They added that by implementing an e-portfolio, students have a record of their progress and feedback from the teacher, so that they can improve their skills. Then, teachers also asked students to do self-assessment. This often happened on students' written projects. When students did self-assessment, students could discover their ability on certain skill. It also means that by doing self-assessment, students can find their weaknesses and their strengths. Besides, students also can learn to be independent and making best decision for their learning process. Lastly, 
teachers' feedback was considered as the important thing in doing formative assessment. Even though teachers' feedback could not train students to be independent, teachers believed that this feedback could provide students with the right direction to improve their ability in certain skill. Those findings was in line with a study conducted by Perera-Diltz and Moe (2014) which stated that there are many aspects of formative assessment and the formative assessment itself can be in the form of self-assessment, peer-assessment, and feedback from instructors. Bhat (2019) in his research showed that descriptive feedback from teachers to their students was the key success of formative assessment. Moreover, Ogange et al., (2018) in their research showed that e-portfolios, peer assessments, self-assessment, offline assignments, and reflection was effective tools of formative assessment in online learning

On the other side, in conducting summative assessment, teachers conducted daily test, mid-terms test, final test in the forms of multiple choice, short answer, and essays, and final project. In this case, the teachers created online quizzes or online test consisted of several questions in the forms of multiple choices, short answers, and essays in forms of google form and shared it via online chat, WhatsApp or via Google Classroom. In Multiple Choice test, teachers made questions through Google form, set the right answer and score scale, so the score automatically appear after students' finished their test and students know directly their score after submitting the test. This is showed on Figure 3 below.

Figure 3. Result of the test

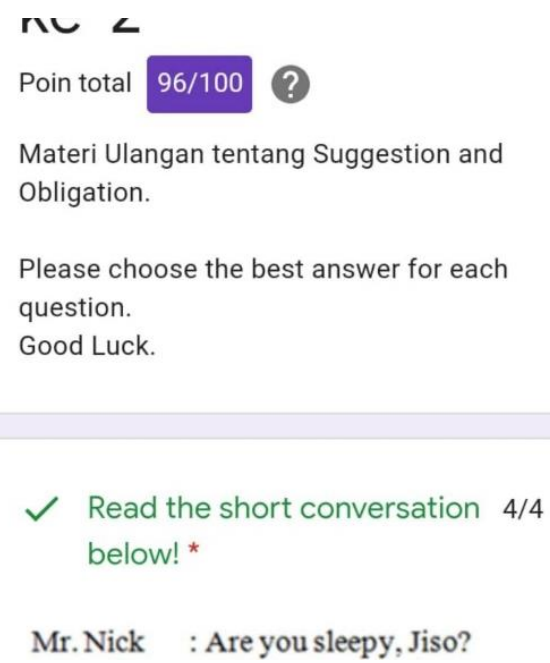

Mr. Nick : Are you sleepy, Jiso?

In the test that required short-answer and essay, the teachers checked it by themselves and give score based on their own rubric score. The example of test given by teachers was showed in Figure 4 below.

Figure 4. Daily Test: short-answer 


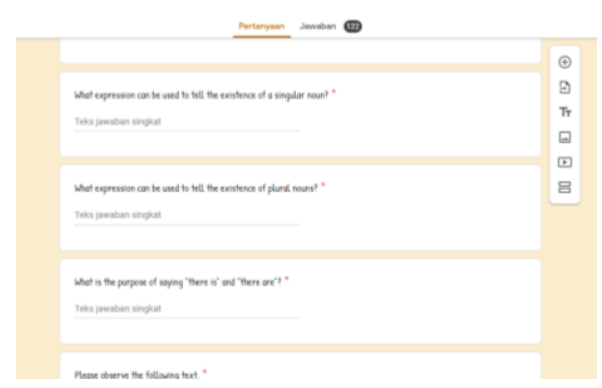

Sometimes, the teachers also assigned the students to do some projects since some teachers apply project-based learning in their online learning. The project was like making birthday card, simple picture dictionary, making wall magazine, and making video about specific topic. In this case, teachers already had their own rubric score to get the final score of the students. The example of the task was showed on Figure 5 below.

Figure 5. Project Task

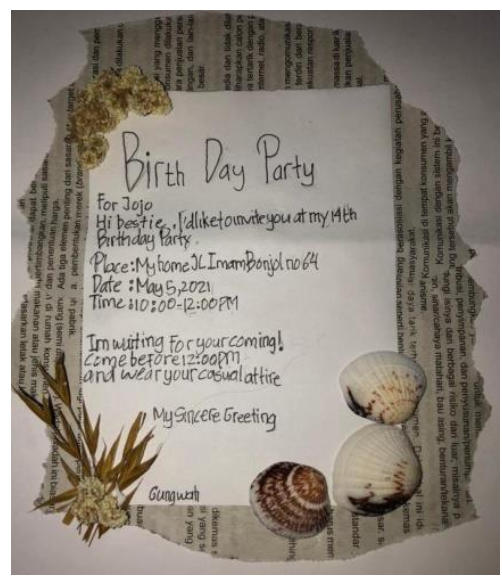

States et al., (2018) stated that Summative assessment includes midterms, final assignments, papers, teacher-designed tests, standardized tests, and high-stakes tests. A study conducted by Parkes and Zimmaro (2018) showed that Multiple Choice Questions (MCQ) is the most common assessment method and is often used in summative assessment. However, multiple choice questions cannot be used to assess higher level skills so it was also found that students who can successfully complete multiple choice questions do not perform well in their essay test. Moreover, they said that essay test should be conducted more often in online environment to practice students' higher order thinking. This also in line with a research conducted by Perera-Diltz and Moe (2014) which stated that Mid-term and final-exam must be given at the end of each semester. This can be done most easily by giving multiple choice questions. However, another option that must also be considered is the provision of long and short answers, to measure students' higher abilities.

The implementation of assessment in today's online learning was quite difficult. Some challenges faced by teachers in doing assessment in online learning in the midst of Covid-19 Pandemic were first, the teachers confused in using different or interesting method of assessment due to the lack of 
assessment literacy. Second, teachers may only use the low-data consuming learning application due to not all students can afford for high-speed internet data package or even a few students do not have internet access at all in their remote areas. These make the assessment process especially in formative assessment not run optimally. Third, some Teachers had problems in accessing technology. Some of the teachers were categorized as an old teacher, impacting on their less ability in struggling with technology. These also related to teachers' digital literacy. Fourth, there is a limitation in accessing the internet. Some of the students lived in a suburban area, impacting less internet access, while others have financial problems. This caused not all students can submit their works inor on- time or even did not submit it and this affected their assessment result. Lastly, the online situation impacted on the difficulty in explaining the feedback. Sometimes, the teachers got frustrated in explaining the feedback online for it was not easy to make sure that the students understood the explained materials. As the impact, there was often miss communication between teachers and students. On the other side, due to the connection problem and students' financial problem caused teachers cannot conduct video conferences which actually can reduce the miss communication. A study conducted by Kimkong and Koemhong (2020) showed that the different level of preparation of teachers and students was the cause of challenges in today's online learning. Then, similar to the results of this study, Kearns (2012) said that the toughest challenge of implementing the assessment in online learning is the problem of using technology and networks to communicate. In addition, teachers are also concerned about the assessment methods they design to monitor the progress and understanding of their students which will affect the provision of feedback for students. In addition, Guangul et al., (2020) in their research showed that The problems that arise in the assessment process during this pandemic were related to infrastructure and the commitment of students to work on and submit their assignments.

Apart from the technical problems, the difficulties felt by teachers were affected by teachers' assessment literacy and digital literacy. According to Mellati and Khademi (2018), assessment literacy is the ability and the knowledge of teachers to design and implement strategies, measurement tools, criteria, and decision-making in providing assessments, both formative and summative. By having assessment literacy, teachers will be able to provide evaluations to students effectively, which can also be used as an evaluation of the teaching and learning process that occurs. In addition, by having an adequate assessment literacy, the teacher will then be able to implement the assessment in every existing condition While according to Vidosavljevic and Vidosavljevic (2019), digital literacy is the ability to use technology or digital equipment properly and appropriately, to communicate with others and build knowledge. Thus, teachers who already have adequate digital literacy will find it easier to use technology to be able to carry out both summative and formative assessments that are right on target. Moreover, teacher also be able to design or create assessment methods critically and creatively.

\section{CONCLUSIONS}

It can be concluded that teachers have been conducting the assessment process, both summative assessment and formative assessment. In conducting formative assessment, teachers used E-portfolios, Self-assessment, and 
teachers' feedback. On the other side, in conducting summative assessment, teachers conducted daily test, mid-terms test, final test in the forms of multiple choice, short answer, and essays, and final project. However, during the implementation, teachers found some difficulties such as the design of the assessment problem, connection problem, Internet data problem, communication problem, and the use of technology problem. Thus, the authorized government and other stakeholders are expected to hold seminar(s) or training(s) for teachers to help them improve their ability in utilizing technology as well as giving assessment in todays' online learning. Besides, the authorized government and other stakeholders are also expected to provide services to help teachers, the school apparatus, and students have a good communication each other. Moreover, apart from technical constraints, teachers are expected to enrich their assessment literacy as well as digital literacy by joining seminar(s), webinar(s), and training(s). By doing so, teachers might reduce the obstacles they face during the implementation and could provide the appropriate assessment for their students.

\section{REFERENCES}

Amaya, P., Agudo, J. E., Sánchez, H., Rico, M., \& Hernández-linares, R. (2013). Educational e-portfolios: Uses and Tools Educational e-portfolios: uses and tools. Procedia - Social and Behavioral Sciences, 93(October), 11691173. https://doi.org/10.1016/j.sbspro.2013.10.009

Ary, D., Jacobs, L. C., \& Sorensen, C. (2010). Introduction to Research in Education (Eighth Edi). CENGAGE Learning.

Bakia, M., Shear, L., Toyama, Y., \& Lasseter, A. (2012). Understanding the Implications of Online Learning for Educational Productivity.

Barbosa, H., \& Garcia, F. (2005). Importance of Online Assessment in the Elearning Process. ITHET 2005: 6th International Conference on Information Technology Based Higher Education and Training, 2005(August), 1-7. https://doi.org/10.1109/ITHET.2005.1560287

Bhat, B. A. (2019). Formative and Summative Evaluation Techniques for Improvement of Learning Process. European Journal of Business and Social Sciences, 7(5), 776-785.

Broadbent, J., Panadero, E., \& Bouda, D. (2018). Implementing Summative Assessment with a Formative Flavour: A Case Study in a Large Class. Assessment and Evaluation in Higher Education, 43(2), 307-322. https://doi.org/10.1080/02602938.2017.1343455

Brookhart, S. M., \& Nitko, A. J. (2019). Educational Assessment of Students. In Pearson.

https://www.researchgate.net/publication/335892361_Item_Discrimination_ and_Distractor_Analysis_A_Technical_Report_on_Thirty_Multiple_Choice_ Core_Mathematics_Achievement_Test_Items\%0Ahttp://www.sciencedirect. $\mathrm{com} / \mathrm{science} / \mathrm{article} / \mathrm{B} 6 \mathrm{~V} 8 \mathrm{~T}-4 \mathrm{FY} 3 \mathrm{~N} X 4-1 / 2 / 6246 \mathrm{a} 8439 \mathrm{f}$

Dhull, I., \& Sakshi, M. (2019). Online Learning. International Education \& Research Journal, 3(May), 6-9.

Guangul, F. M., Suhail, A. H., Khalit, M. I., \& Khidhir, B. A. (2020). Challenges of Remote Assessment in Higher Education in the Context of COVID-19: A Case Study of Middle East College. Educational Assessment, Evaluation and Accountability, 32(4), 519-535. https://doi.org/10.1007/s11092-02009340-w 
Kearns, L. R. (2012). Student Assessment in Online Learning: Challenges and Effective Practices. 8(3), 198-208.

Kimkong, H., \& Koemhong, S. (2020). Online learning during COVID-19: Key Challenges and Suggestions to Enhance Effectiveness. Cambodian Education Forum (CEF), December, 1-15. https://www.researchgate.net/publication/346719308_Online_learning_duri ng_COVID-

19_Key_challenges_and_suggestions_to_enhance_effectiveness

Lauder, A. (2008). the Status and Function of English in Indonesia: a Review of Key Factors. Makara Human Behavior Studies in Asia, 12(1), 9. https://doi.org/10.7454/mssh.v12i1.128

Lestari, R. P., Asrori, M., \& Sulistyawati, H. (2019). The English Teaching Strategies for Young Learners in an International Primary School in Surakarta. Jurnal Universitas Sebelas Maret, 7(2), 190-198.

Mellati, M., \& Khademi, M. (2018). Exploring Teachers' Assessment Literacy: Impact on Learners' Writing Achievements and Implications for Teacher Development. Australian Journal of Teacher Education, 43(6), 1-18. https://doi.org/10.14221/ajte.2018v43n6.1

Miles, M. B., Huberman, A. M., \& Saldaña, J. (2014). Qualitative Data Analysis: A Methods Sourcebook (3rd editio). SAGE Publications.

Nguyen, H., \& Terry, D. R. (2017). English Learning Strategies among EFL Learners: A Narrative Approach. Journal of Language Learning, 3(1), 4-19.

Nishanthi, R. (2018). The Importance of Learning English in Today World. International Journal of Trend in Scientific Research and Development, 3(1). https://doi.org/10.31142/ijtsrd19061

Ogange, B. O., Agak, J., Okelo, K. O., \& Kiprotich, P. (2018). Student Perceptions of the Effectiveness of Formative Assessment in an Online Learning Environment. Open Praxis, 10(1), 29. https://doi.org/10.5944/openpraxis.10.1.705

Parkes, J., \& Zimmaro, D. (2018). Formative and Summative Assessments. The College Classroom Assessment Compendium, 1983, 89-91. https://doi.org/10.4324/9781315283852-25

Perera-Diltz, D., \& Moe, J. (2014). Formative and Summative Assessment in Online Education. Journal of Research in Innovative Teaching, 7(1), 130142.

Qu, W., \& Zhang, C. (2013). The Analysis of Summative Assessment and Formative Assessment and Their Roles in College English Assessment System. Journal of Language Teaching and Research, 4(2), 335-339. https://doi.org/10.4304/jltr.4.2.335-339

Shaoqian, L. (2003). The Research of English Classroom Teaching. Foreign LAnguage Teaching and Research Press.

States, J., Detrich, R., \& Keyworth, R. (2018). Summative Assessment. https://doi.org/10.13140/RG.2.2.16788.19844

Vidosavljevic, M. M., \& Vidosavljevic, S. T. (2019). The Importance of Teachers ' Digital Literacy. December 2019, 415-426.

Wojtczak, A. (2002). Medical Education Terminology. Medical Teacher, 24(4), 357-453. https://doi.org/10.1080/0142159021000000861 